\title{
The Implementation of Preferential Procurement Policy in Gauteng Province Challenges and Solutions
}

HLAKUDI, John Nkwananchi

\section{Abstract}

he South African government
established the Preferential Procurement Policy (PP Policy) to provide Historically Disadvantaged Individuals (HDIs) economic opportunity in the state procurement process. There were a number of challenges in the implementation of the policy. The challenges include non compliance with procurement processes, limited knowledge of preferential procurement targets, late payments of suppliers, and fraud and corruption. In addition to putting measures to improve inefficiencies embedded in the preferential procurement system, this article asserts that the achievement of the objectives of the

Preferential Procurement Policy lies mainly in the commitment by top management and the empowerment of the people tasked with the implementation of the policy. This means that the top management should receive training about the importance of the policy to create economic opportunities for black people. Furthermore, Supply Chain Management (SCM) officials in government should be given appropriate authority in the public procurement system.

Keywords: Procurement, Equity, Preferential Procurement, Public Procurement Policy. 


\section{Introduction}

It is accepted that the democratic South Africa is still characterised by poverty and inequalities along racial lines (Mabeta, 1991: 2 and Asaf, Cato, Jawoko and Rosevear, 2010: 22). The Preferential Procurement Policy is one of the policies that aim to redress these inequalities inherited from the previous apartheid regime by creating an enabling environment for black South Africans to participate in the mainstream economy. However, since its implementation a decade ago, the policy is not an exception to unintended challenges and problems. As a result, the process of economic transformation is too slow and the intended benefits of the policy are not realised according to the targets that the government has set to achieve (Hlakudi, 2012).

The purpose of this article is to investigate the challenges facing the implementation of Preferential Procurement Policy in Gauteng Provincial Government (GPG) and propose actions that need to be implemented to redirect procurement opportunities to black South Africans. The article presents part of the findings of the Masters Report by Hlakudi (2012). This is similar to a study by Magoro and Brynard (2010) that investigated the challenges associated with the implementation of preferential procurement in the delivery of low cost housing programme. This article does not focus on a specific programme or category of goods and services, but rather aims to investigate the challenges in general irrespective of the goods or services involved.

The article begins with the description of the methodology used to collect and analyse data. The conceptualisation of procurement with all the principles that characterise good public procurement system is then considered. Among these principles, the principle of equity and its relation to the emergence of preferential procurement phenomenon is given a detailed examination. The results of the article are presented as challenges for implementation and recommendations are made to mitigate the situation.

\section{Methodology}

The article followed the qualitative research method. The word qualitative implies an emphasis on the qualities of entities and on processes and meanings that are not experimentally examined in terms of quantity, amount, intensity, or frequency. Qualitative researchers seek answers to questions that explain how social life experience is created 
and given meaning (Denzin and Lincoln, 2005: 10). According to Denzin and Lincoln (2005: 2) there are many methods and approaches that fall under the category of qualitative research, such as case study, politics and ethics, participatory, inquiry, interviewing, participant observation, and interpretative analysis. The article is based on the case study of Gauteng. The interviewing method was used to collect the data. Interviewing took the form of individual as well as focus group interviews.

Some of the reasons for the use of qualitative research as cited by Ospina (2004) are as follows:

- To add a rich detail to the existing knowledge that was generated quantitatively. In-depth interviews revealed complex phenomenon of "limited knowledge of preferential procurement targets" which would have been hidden by selfdefence syndrome as it exposes a weakness on the part of the respondents.

- To advance a novel perspective of a phenomenon well studied quantitatively but not well understood because of the narrow perspectives used before. The qualitative research allowed the respondents to suggest innovative solutions to improve the implementation of preferential procurement such as ring-fencing of the budget.

- To understand complex phenomenon that are difficult to capture quantitatively. The qualitative research process revealed that the challenges relating to the implementation of PP Policy are exacerbated by lack of accountability and bureaucratic arrangements in government that do not provide adequate authority to supply chain managers.

These reasons explain the importance of qualitative research to the extent that some phenomena are so complex that they cannot be studied quantitatively, but rather qualitatively. This makes qualitative inquiry an indispensable approach in the study of reality that involves human element.

\section{Individual interviews}

The researcher collected primary data from interviews with relevant officials from Gauteng Provincial Government and National Treasury. A number of five officials from Gauteng Provincial Government were interviewed. These officials are responsible for the 
procurement of goods and services on behalf of Gauteng Provincial Departments. One official from National Treasury's Supply Chain Management unit was also interviewed to obtain information from the custodians of the Preferential Procurement Policy in the Republic. The data was collected from six officials responsible for Supply Chain Management and procurement in Gauteng Provincial Government and National Treasury.

The selection of respondents was based more on experience, expertise, the seniority and the relevance of the respondents concerned to the study in order to ensure that more credible data is collected. The author used open-ended questions to obtain the informant's opinion on the topic under consideration (Tellis, 1997: 8). The interviews with five respondents were audio-tape recorded on their permission and transcribed to enhance the reliability of the data. One respondent did not consent to be audio-tape recorded and as a result, extensive notes were taken in order to capture all the relevant information that was provided.

The interviewer introduced the topic to each research respondent by outlining the purpose of the interview before the start of the interviewing session. The researcher also asked clarity seeking questions of key statements or words as introduced by the interviewees to avoid ambiguities and enable good analysis of the data (Kvale 1996: 132). According to Rubin and Rubin (2005: 136) follow-up questions are crucial for obtaining depth and detail, and can help in obtaining more nuanced answers. The researcher also debriefed the respondents after each interview by highlighting key lessons learned from the interview process (Kvale 1996: 128).

\section{Focus groups}

Focus groups are also described as group in-depth interviews. These groups consist of a small number of individuals or interviewees that are drawn together for the purpose of expressing their opinions on a specific set of open questions (Welman, et al., 2005: 201). Focus groups have been used successfully in many areas of research (Barry, Steyn, and Brent, 2009: 231). Two focus group interviews were conducted. The first group consisted of five participants while the second group consisted of three participants who are experts or practitioners in supply chain management and procurement. The people who participated in the individual interviews did not form part of these groups. 
The interviewing processes of the two focus group sessions were not audio-tape recorded as some of the participants did not give their consent. Extensive notes were then taken. As recommended by Barry, et al., (2009: 239) the nominal group technique must be used during the focus group to give the participants the opportunity to generate ideas in isolation. Participants of the focus groups were also given a piece of paper to summarise their opinions about the topic at the end of each group interview session. Only two participants of the focus groups returned their written summarised opinions about the topic. The questions of the focus groups were developed and refined after the individual interviews in order to cover areas of the research that were not adequately addressed during the individual interviewing process. The focus group data supplemented the data from the individual interviews to allow ease of analysis of data.

\section{Data analysis}

According to Rubin and Rubin (2005: 201) data analysis is the process of moving from raw interviews to evidence based interpretations that are the foundation for published reports. Data analysis consists of examining, Categorising, tabulating, or otherwise recombining the evidence to address the initial propositions of the study (Yin, 1994). The data collected was analysed and compared with the literature on the challenges for the implementation of PP Policy. The techniques used to analyse the data include preparing field notes and transcribing as well as theme identification.

Detailed notes acquired manually and through tape recordings were compiled during qualitative interviewing and converted into write-ups to enable ease of reading and editing (Welman, et al., 2005: 211; Kalof, et al., 2008: 203). Kvale (1996: 170) indicated that the process of transcribing of tape recordings may take the form of rephrasing and condensing of statements if the aim is to give some general impressions of the research participant's views and categorises the data.

Themes are described as umbrella constructs which are usually identified by the researcher before, after and during data collection. Themes that emerged during the data analysis process were identified in the form of challenges facing the implementation of PP Policy such as non compliance with procurement processes, limited knowledge of preferential procurement targets, late payments of suppliers, and fraud and corruption. The researcher searched for word repetitions and keywords in context to establish the 
themes (Welman, et al., 2005). A qualitative researcher analyses data by organising it into categories on the basis of themes, concepts or similar features (Neuman, 2006: 460).

\section{Procurement}

Pauw, Woods, Van der Linde, Fourie, and Visser (2002: 227) define procurement as the acquisition of goods and services other than the services of officials, for the people and their administration by means of commercial transactions. In addition, procurement may be defined as the process which creates, manages and fulfils contracts relating to:

- The provision of supplies, services or engineering and construction works;

- The hiring of anything;

- Disposals; and

- The acquisition or granting of any rights and concessions (Construction Industry Development Board, 2010).

Public procurement refers to those government administrative activities that concern the purchasing of the goods and services that the government needs from the private sector. These range from basic stationery requirements and other consumables through to mainframe computer systems, weapons and large public buildings (Pauw, et al., 2002: 227).

According to Pouris, et al., (2001; cited in Pauw, et al., 2002: 228) the goals of public procurement are to obtain optimum supply of goods and services from the market in terms of quality, timeliness and cost, while at the same time minimising risks, accomplishing socio-economic objectives, including competition and maintaining integrity. According to De La Harpe (2009) procurement has two main objectives namely: primary and secondary objectives. Primary objectives relate to the achievement of value for money for the procuring entity, fairness of the process on the part of the suppliers, transparency and accountability to the public as the taxpayers who finance government procurement. The secondary objectives relate to procurement as an instrument to address socio-economic issues (De La Harpe, 2009). The procurement process that supports the secondary objectives is called preferential procurement. According to Watermeyer (2003: 2) PP Policy is a procurement policy that promotes objectives in addition to those associated with the immediate objectives of procurement itself. 
According to Magoro (2010: 69) the primary objectives of the procurement policy that is fair, equitable, transparent, competitive and cost effective are undermined by the secondary objectives of considering categories of groups of people who were previously disadvantaged, including people with disabilities, women and youth. In contrast, the procurement system in South Africa only allocates 10 or 20 points out of 100 points to the achievement of the secondary objectives of procurement (Preferential Procurement Regulations, 2011). The possibility of undermining the primary objectives can happen only if the procurement system is not applied correctly.

According to Bolton (2006: 195) using procurement as a policy tool can also be referred to as "wealth redistribution," that is, the process that redirects economic resources to previously disadvantaged groups in society. This is true because preferential procurement provides employment and business opportunities for marginalised individuals and communities (Govender and Watermeyer, 2000).

In terms of Section 217 of the Constitution of the Republic of South African Act, 108 of 1996 read in conjunction with section 38 of the Public Finance Management Act (PFMA), 1 of 1999 and chapter 11 of the Municipal Finance Management Act (MFMA), 53 of 2003 require all organs of state in the national, provincial and local sphere of government to procure for goods and services in accordance with a system that is fair, transparent, equitable, competitive, and cost effective. All public procurement activities that are inconsistent with these legislative provisions are unconstitutional and should be prohibited. These legislative provisions for a system of public procurement are referred to as the pillars or principles of procurement. It is important to look at these pillars in more detail as preferential procurement emanates from one of these principles, namely equity. Preferential procurement is therefore one of the principal hallmarks of a public procurement system.

\section{Principles of procurement}

Preferential procurement and other principles of procurement form the conceptual framework of this article. Procurement, like any other profession or practice, is guided by a set of principles that define the ethical considerations for the profession or practice. De La Harpe (2009) noticed that these public procurement principles, such as open tender procedures, existed in the two colonies (Natal and Cape) and two Republics (Orange Free State and Transvaal) at the beginning of the $20^{\text {th }}$ century. 
South Africa has established principles of procurement long ago and most of these principles are found in present day procurement system in the country. The two republics had procurement provisions under their constitutions which were aligned to the Roman Dutch Law while Natal and the Cape had to apply these principles under the Roman Dutch Law (De La Harpe, 2009). However, equity principle or preferential procurement was not part of the legal provisions for public procurement during that time. The obvious reason for this could be that the government did not realise a need for empowerment of black owned companies as oppression of black people was part of government policy.

According to National Treasury (2009) proper and successful government procurement rests upon certain core principles of behaviour, the five pillars of procurement. The pillars are: value for money, fairness, transparency, equity, and competition. They are best described as pillars because if anyone of them is broken the procurement system falls down (National Treasury, 2009). Furthermore, De La Harpe (2009) identified nine principles applicable to public procurement as follows: economy, competitiveness, effectiveness, transparency, the combating of abuse, the avoidance of risk, accountability, fairness and equitability, and integrity. In addition the World Bank (2001) identified similar principal hallmarks of proficient public procurement as De La Harpe (2009) with the exception of efficiency and reliability. The mere existence of these ethical principles in government policies may not be regarded as a panacea for a good public procurement system, but rather the effective implementation of the principles. The focus of this article is on the implementation of the principle of equity. Therefore, a brief explanation of the principle of equity that underlies the preferential procurement system is important.

\section{Equity principle}

Equity as a pillar of procurement lays the foundation for preferential procurement, which is the focus of this article. According to Pauw and Wolvaardt (2009: 74) equity is about the allocation of resources to certain groups that were disadvantaged by apartheid. The word equity means the application and observance of government policies which are designed to advance persons or categories of persons disadvantaged by unfair discrimination. It is only fair to give the disadvantaged groups an advantage during the tender process at this stage of a democratic South Africa (Pauw and Wolvaardt, 2009: 
The Implementation of Preferential Procurement Policy in Gauteng Province 63

74). Equity ensures that government is committed to economic growth by implementing measures to support industry generally, and especially to advance the development of emerging enterprises and historically disadvantaged individuals (National Treasury, 2009).

\section{Preferential Procurement System}

Preferential procurement is derived from the equity principle as prescribed by section 217 of the Constitution of the Republic of South Africa Act, 108 of 1996. Similar to affirmative action, preferential procurement is the policy of the South African government aimed at redressing the imbalances of the past through the awarding of government contracts. Preferential procurement seeks to advance HDIs in allocating contracts for the provision of goods, services and works for service delivery purposes. Preferential treatment allows an individual's status as a minority to be considered a positive factor among other factors when allocating opportunities and benefits (Starks, 1992: 942; cited in Erasmus, et al., 2005: 163). Louw (2010: 82) affirms that preferential procurement creates employment and business opportunities to disadvantaged people and communities. However, procurement opportunities that are awarded to emerging enterprises owned by HDIs in Gauteng are still below the provincial target (Hlakudi, 2012).

The term preferential procurement bears the same features as affirmative action in the United States of America (USA). According to McCrudden (2004: 260) the term affirmative action gained popularity during the 1960s with the aim of achieving greater equality for the disadvantaged groups in USA. As Starks (1992: 939; cited in Erasmus, et al., 2005: 163) indicated that affirmative action policies are frequently used in awarding business contracts, in hiring and promotions, and in university admissions and granting of scholarships. In South Africa the concept of affirmative action is limited to transformation in the workplace. In terms of section 15 of the Employment Equity Act, 55 of 1998 affirmative action measures aim to ensure that people from designated groups have equal employment opportunities and are equitably represented in all occupational categories and levels in the workforce.

According to the Draft Codes of Good Practice for BBBEE (2004) preferential procurement is a measure designed to widen market access for entities, in order to integrate them into the mainstream of the economy. Preferential procurement encourages and facilitates the adoption of BBBEE by aligning business imperatives to 
BBBEE. Preferential procurement will create economic empowerment benefits indirectly but meaningfully as it multiply the effects of private and public sector interventions to promote BBBEE (Department of Trade and Industry, 2004). According to the Codes of Good Practice for BBBEE (2007) the ownership and preferential procurement element each carries the highest weight (20 points) as compared to the other elements. This is an indication that preferential procurement is regarded as the key instrument that can be implemented to accelerate the achievement of the objectives of BBBEE in South Africa.

In Gauteng Province, and South Africa in general, preferential procurement uses the point system in the awarding of contracts. The PPPFA and its associated Regulations (2011) established the $80 / 20$ and $90 / 10$ scoring models that must be used to evaluate tender offers. The 80/20 apply to contracts with an estimated value of R1 million and below, and the 90/10 apply to contracts estimated to exceed R1 million. The 20 points and 10 points are awarded to companies owned by black people according to the BEE status level of contribution when using the 80/20 and 90/10 respectively. The PPPFA and its associated regulations changed the use of price as the only decisive criterion for the award of contracts. However, the fact that the full 80 or 90 points out of a total of 100 points are still allocated to price indicates that the new procurement regime still recognises price as a very important criterion (Bolton, 2007: 49). The 20 and 10 points are therefore regarded as the preference points. The aim of this preferential system is to promote socio-economic development in the country. As part of its transformation, modernisation and reindustrialisation agenda, Gauteng Province earmarked the revitalisation of township economies through preferential procurement (Makhura, 2014).

The 80 and 90 points are points for price. A bidder with the lowest price will automatically receive 80 or 90 points depending on the estimated value of the contract. The company that is awarded the contract should score the highest points, which is a combination of points for price (80 or 90 ) and preference points (20 or 10). A company which is not BEE accredited does not qualify for preference points and therefore competes with only the points for price ( 80 or 90 ). The BEE accredited companies have an advantage over non-BEE accredited counterparts because they receive additional 20 or 10 points, which the non-BEE accredited counterparts do not receive. The system only gives preference to BEE accredited companies through the award of preference points (Preferential Procurement Regulations, 2011). 


\section{Methods used to implement preferential procurement}

Table 1 below presents different methods that are used to implement preferential procurement.

\section{Table 1: Methods used to implement preferential procurement}

Set asides

Qualification criteria

Contractual conditions

Offering back

Product or service specification

\section{Preferences at the short listing stage}

Tender evaluation criteria

General assistance
Only the enterprises with specific characteristics required by the procuring entity are allowed to compete for contracts reserved for their exclusive execution.

Enterprises that do not meet specified requirements relating to PP Policy objectives are excluded from participating in contracts other than those provided for in the law.

The method makes policy objectives a contractual obligation. The contractor that is awarded the contract through a competitive bidding process is required to subcontract a percentage of the contract to SMMEs or form a joint venture with a company owned by HDIs.

The procuring entity offers tenderers that satisfy criteria relating to policy objectives an opportunity to execute the contract or part of the contract if that tenderer is prepared to match the price and quality of the best tender received.

The procuring entity state requirements in product or service specifications, e.g. by specifying labour based construction methods where procurement is used as a policy tool for employment creation. In South Africa all contracts under the Expanded Public Works Programme (EPWP) have mandatory condition for the excessive use of labour, unskilled labour in particular, to create job opportunities for the poor.

Limit the number of suppliers or service providers who are invited to tender on the basis of qualifications and give a weighting to policy objectives along with usual commercial criteria, such as price and quality, at the short listing stage.

The procuring entity gives a weighting to PP Policy objectives along with usual commercial criteria, such as price and quality, at the award stage.

The government in South Africa provides assistance for targeted groups to compete for business. The support is evident in the SMME support agencies established in South Africa.

Source: Watermeyer, 2003 
There are other methods that are used to implement preferential procurement which include the design of specifications, contract conditions and procurement processes to benefit particular enterprises. Furthermore, the procuring entity may design specifications and / or set contract terms to facilitate participation by targeted groups of suppliers (Watermeyer, 2003: 5).

\section{Findings: Challenges to procurement}

The country still has considerable obstacles to overcome in order to achieve equity among all citizens (Antonites and Truter, 2010: 447). Magoro (2010) identified some of the challenges facing the implementation of preferential procurement as limited capacity of procurement officials in government, political interference, lack of capacity of contractors, and corruption. Similarly, Hlakudi (2012) identified the challenges of implementation as, amongst others, lack of top management support, fraud and corruption, inconsistency between the PPPFA and BBBEEA, and the rule driven nature of the procurement processes. According to Hlakudi (2012) all these challenges render the process of empowering HDIs to be very slow. Some of these challenges are considered in detail below.

\section{Non compliance with procurement processes}

According to Auditor General Report (2010) seven departments and nine provincial entities in Gauteng incurred irregular expenditure of R1, 5 billion and R464, 4 million respectively during the 2009/2010 financial year due to non compliance with laws and regulations that govern supply chain management processes. Departments and public entities further incurred fruitless and wasteful expenditure due to various reasons including late payments of accounts (Auditor General, 2010). The Auditor General (2010) identified, amongst others, the following issues of non compliance with SCM legislation:

- Departments and entities failed to invite three quotations for procurement of the value below R500 000 .

- Departments failed to invite competitive bids for procurement of the value above R500 000. 
- Contracts were awarded to suppliers who failed to provide original valid tax clearance certificates.

- $\quad$ The preference point system was not always applied.

- Tender awards were made to suppliers who did not score the highest points (Auditor General, 2010).

\section{Limited knowledge of preferential procurement targets}

The majority of the participants are not familiar with the department's targets to achieve preferential procurement. The participants could not indicate the targets without referral to the source documents. As the participants were procurement practitioners who implement preferential procurement on daily basis, it is reasonably expected that they should be familiar with the targets that the department is working to achieve.

\section{Late payments to suppliers}

The government takes long to pay its suppliers. The payment cycle of 30 days in terms of Treasury Regulations (2005) is often not met. This creates cash flow problems for the SMME suppliers as they then fail to meet their financial obligations to their employees and financial institutions that lend money to them. Consequently, Phago and Tsoabisi (2010) noted that delays in payment resulted in the closure of business operations by some SMMEs.

\section{Fraud and corruption}

The companies that are doing business with the government tend to engage in fraudulent activities by claiming preferential procurement points that they do not deserve. This is called fronting. The procurement process then becomes flawed as companies win government contracts because of preference points that they do not deserve. This process disadvantages the emerging HDI owned companies as their prospects of success lies on the award of preference points. Corruption is continually revealed in the field of public procurement than other areas of public affairs (Arnáiz, 2006: 1). This undermines value for money and the objectives of the procurement policy to achieve certain socio-economic objectives (Magoro and Brynard, 2010: 15). 
All these challenges create a difficult business environment for emerging enterprises. Similarly, Antonites and Truter (2010) identified some of the challenges facing emerging enterprises as cash flow problems, lack of generic business skills and expertise, lack of knowledge of government procurement requirements, long payment cycles and poor communication of available opportunities and support programmes by government. The result is that all the efforts of government are then eroded.

\section{Recommendations}

The following recommendations are made to accelerate the achievement of the objectives of Preferential Procurement Policy:

\section{Improving accountability}

The National Treasury and other relevant stakeholders need to raise awareness of the importance of Preferential Procurement Policy in the country. In addition to setting targets that must be achieved by government, procurement officials should be accountable to the political leadership of the province such as the Standing Committee on Public Accounts (SCOPA) on the implementation and the achievement of the targets for preferential procurement. The current reporting process on the achievement of PPPFA objectives to National Treasury does not hold officials accountable for their reports. The failure to achieve departmental targets for PP Policy should be linked to the performance of the officials tasked to implement the policy. Improved accountability will drive procurement officials to be vigilant and always seek alternative ways of improving performance against the targets.

In support of this recommendation, Oguonu (2007: 97) recommended that public procurement be subject to due process to eliminate corruption. The due process and procurement reforms would result in a more transparent, efficient and effective procurement system which creates equal access to bidders of public sector contracts (Oguonu, 2007: 97). The due process implies that government activities and businesses can be carried out openly, economically and transparently without favouritism and corruptible tendencies (Ezekwesili, 2004; in Oguonu 2007: 93). 
This shows that accountability will serve to achieve two milestones at the same time. The first one is to improve performance against the preferential procurement targets, and the second one is to eliminate corruption in the preferential procurement system.

\section{Ring-fencing the budget}

The Gauteng Provincial Government needs to take strict measures to ensure that funds are geared towards the empowerment of emerging enterprises owned by HDIs. This means that a portion of the budget for goods and service should be fixed for spending on certain categories of the HDIs. This fixed portion should not exceed the percentage targets set for the empowerment of HDI owned companies. This process of fixing the budget should have a provision for deviation from the fixed amount in order to ensure that the principles of procurement are still implemented and the process does not exclude certain categories of service providers and suppliers. No literature could be sourced that support this recommendation.

\section{a. Linking management performance to preferential procurement}

The objectives of PP Policy cannot be achieved without the support of all the members of the top management as they are the budget holders. As a result, there is a need to provide regular workshops on the implementation of preferential procurement to the members of the top management of GPG. When all the members of the top management are conversant with the broader objectives of preferential procurement, the performance management system of the top management should be modified to incorporate preferential procurement element. This will ensure that the spending of the budget by top management will take into account the preferential procurement objectives and targets of the organisation which will also form part of their performance assessments. This process will also facilitate transformation in other areas or commodity and service categories that are historically white dominated.

\section{b. Empowering the implementers}

The SCM officials have the mandate to oversee and facilitate the implementation of SCM policies in departments. It is common logic that the 
implementers will be able to carry their mandate if they are given the required level of authority over their roles and responsibilities. This simply means that the SCM officials should be given the authority that is sufficient for them to effect the necessary measures to achieve the targets set for HDIs. These measures may include incubation programmes for certain categories of HDIs, obligations for joint ventures and proper rotation of service providers. The empowerment of SCM officials will require the review of SCM delegations to give them authority to control the procurement process in line with applicable policies. The SCM officials should also have a strong voice in the evaluation and award of contracts in GPG. The approval of all transactions with financial implications for the department should be supported by the SCM office.

\section{Conclusion}

The government and many South Africans have hope that the implementation of Preferential Procurement Policy will strive to stimulate the culture of entrepreneurial orientation among black citizens. The ultimate goal is to create a new South Africa that is not defined by racial inequalities inherited from the previous apartheid regime. The current challenges were not anticipated to create difficulties of implementation. However, the implementation of the recommendations in this article has a potential to realise positive results.

In addition to putting measures to improve inefficiencies embedded in the procurement system, this article contends that the achievement of the objectives of Preferential Procurement Policy lies mainly on the commitment by top management and the empowerment of the people tasked with implementation of the policy. This means that the top management should be sensitised through some form of training about the importance of the policy in creating economic opportunities for black people. Furthermore, government officials who are responsible for the implementation of SCM policy in their respective departments should be given appropriate authority in the public procurement system. 
The Implementation of Preferential Procurement Policy in Gauteng Province 71

\section{List of References}

- Antonites, A.J. and Truter, M. 2010. SMME Procurement Issues in Local Government: A Gauteng Metropolitan Study. Journal of Public Administration, 45, Issue 3, September, $447-466$.

- Arnáiz, T.M. September 2006. Grounds for exclusion in public procurement: Measures in the fight against corruption in European Union. International Public Procurement Conference Proceedings.

- $\quad$ Asaf, Z., Cato, N., Jawoko, K., and Rosevear, E. 2010. Promise Unmet? Addressing Inequality in Post-Apartheid South Africa. Toronto: University of Toronto.

- Auditor General of South Africa. 2010. General Report on the Provincial Audit Outcomes of Gauteng 2009 -2010, South Africa.

- Barry, M.L., Steyn, H. and Brent, A. 2009. The use of the focus group technique in management research: The example of renewable energy technology selection in Africa. Journal of Contemporary Management, 6, 229-240.

- Berry, A., Von Blottnitz, M., Cassim, R., Kesper, A., Rajaratnam, B. and Van Seventer, D.E. 2002. The Economics of SMMEs in South Africa. Trade and Industrial Policy Strategies (TIPS).

- Bolton, P. 2006. Government Procurement as a Policy Tool in South Africa. Journal of Public Procurement. 6, Issue 3, 193-217, South Africa: PrAcademics Press.

- Bolton, P. 2007. An Analysis of the Preferential Procurement Legislation in South Africa. Public Procurement Law Review, 16, Issue1, 36-67: Sweet \& Maxwell and contributors.

- De La Harpe, S.P.L.R. 2009. Public Procurement Law: A Comparative Analysis, South Africa: University of South Africa.

- Denzin, N.K. and Lincoln, Y.S. 2005. The Sage Handbook of Qualitative Research (3rd ed). United Kingdom, California: Sage Publications, Inc.

- Department of Trade and Industry. 2004. Draft Codes of Good Practice for Broad Based Black Economic Empowerment, Pretoria: Government Printing Works.

- Erasmus, B., Swanepoel, B., Schenk, H., Van der Westhuizen, E.J. and Wessels, J.S. 2005. South African Human Resource Management for the Public Service, Cape Town: Juta \& Co, Ltd. 
- Govender, J.N. and Watermeyer, R.B. 2000. Potential procurement strategies for construction industry development in the SADC region.

- Hlakudi, N.J. 2012. Preferential Procurement and Emerging enterprises. Masters Dissertation, Johannesburg: University of Witwatersrand.

- Kalof, L., Dan, A. and Dietz, T. 2008. Essentials of Social Research, Berkshire: Open University Press.

- Kvale, S. 1996. Interviews: An Introduction to Qualitative Research Interviewing, California: Sage Publications.

- $\quad$ Louw, N.H. 2010. Public Sector Procurement. IMIESA, October. 81 - 84.

- Mabeta, K.M. 1991. Black Economic Empowerment: A Conceptual Analysis, Johannesburg: University of the Witwatersrand.

- Magoro, M.J. 2010. The implementation of the procurement policy with reference to the Reconstruction and Development Housing programme in Limpopo province. Masters Dissertation, Pretoria: University of Pretoria.

- Magoro, M.J. and Brynard, P.A. 2010. Difficulties Associated with the Implementation of the Preferential Procurement Policy in Conjunction with a Low Cost Housing Programme: A South African Contextualisation. Politeia, 29, Issue 3, 4-23.

- Makhura, D. 2014. State of the Province Address, Gauteng Province: Office of the Premier.

- McCrudden, C. 2004. Using public procurement to achieve social outcomes. Natural Resources Forum, Oxford: Blackwell Publishing.

- National Treasury. 2009. General Procurement Guidelines, Pretoria.

- Neuman, W.L. 2006. Social Research Methods: Qualitative and Quantitative Approaches (6 $6^{\text {th }}$ ed.), New York: Pearson Education, Inc.

- Oguonu, C.N. 2007. Due Process and Procurement in the Nigerian Public Sector. African Renaissance. 4, 1, Quarter 1. 91 - 99.

- Ospina, S. 2004. Qualitative Research. Encyclopedia of Leadership, London: Sage Publications.

- Pauw, J.C. and Wolvaardt, J.S. 2009. Multi-criteria decision analysis in public procurement a plan from the South. Politeia. 28, Issue 1, 66 - 88, Pretoria: Unisa Press. 
- Pauw, J.C., Woods, G., Van der Linde, G.J.A., Fourie, D. and Visser, C.B. 2002. Managing Public Money: A System from the South, Sandown: Heinemann Publishers (Pty) Ltd.

- Republic of South Africa. 1996. Constitution of the Republic of South Africa Act 108 of 1996, Pretoria: Government Printers.

- Republic of South Africa. 1998. Employment Equity Act 55 of 1998, Pretoria: Government Printers.

- Republic of South Africa. 2003. Municipal Finance Management Act 56 of 2003, Pretoria: Government Printers.

- Republic of South Africa. 2000. Preferential Procurement Policy Framework Act 5 of 2000, Pretoria: Government Printers.

- Republic of South Africa. 2011. Preferential Procurement Regulations, Pretoria: Government Printers.

- $\quad$ Republic of South Africa. 2005. Treasury Regulations, Pretoria: Government Printers.

- Rubin, H.J. and Rubin, I.S. 2005. Qualitative Interviewing: The art of hearing data (2nd ed.), California: Sage Publications.

- Tellis, W. 1997. Application of a case study methodology. The Qualitative Report, 3, Issue 3, September, 1-17.

- Watermeyer, R.B. 2003. Implementing preferential procurement policies in the public sector in South Africa. Journal of the South African Institution of Civil Engineering. 45, Issue $3, \mathrm{P} 1-20$

- Welman, J.C., Kruger, S.J. and Mitchell, B.C. 2005. Research Methodology (3rd ed), Cape Town: Oxford University Press, Southern Africa.

- Yin, R. 1994. Case study research: Design and methods (2nd ed), Thousand Oaks CA: Sage Publishing.

\section{AUTHOR'S CONTACT:}

\section{HLAKUDI, John Nkwananchi}

Gauteng Provincial Treasury Email: John.Hlakudi@gauteng.gov.za 